\title{
The Effect Of Stock Price, Share Return, Share Trading Volume, And Return Variant On Bid-Ask Spread On Textile And Garment Companies Listed On The Indonesia Stock Exchange, 2019-2020
}

\author{
Heny Sidanti, ${ }^{1}$ Annisa Istikhomah ${ }^{2}$ \\ Tax Management Study Program \\ PGRI Madiun University \\ ${ }^{*}$ Corresponding Author : \\ Email : henysidanti75@gmail.com
}

\begin{abstract}
This study aims to obtain empirical evidence of the effect of Stock Price, Stock Return, Stock Trading Volume, and Return Variant on the Bid-Ask Spread of Stocks in Textile and Garment Companies Listed in Indonesia Stock Exchange in 2019-2020. The stock price used is the stock price recorded at the end of each closing period (closing price), stock returns are measured using the difference between returns on the research day and before the study divided by returns on the day before the study, stock trading volume is measured by the number of shares traded at the time of the study. $t$ is divided by the number of shares outstanding at the time of the study, the variance of stock returns is measured using the standard deviation, and the bid-ask spread is measured by the difference between the selling price and the purchase price divided by the difference between the selling price and the purchase price divided by two. The population in this study is 17 textile and garment companies listed on the IDX. Based on the purposive sampling method, a sample of 16 companies was obtained with 309 data. This research data is obtained from the company's monthly data from 2019 to 2020. The results of the analysis show that stock prices and stock trading volumes affect the bid-ask spread, while stock returns and return variances do not affect the bid-ask spread. Meanwhile, simultaneously, stock prices, stock returns, stock trading volume, and return variance affect the bid-ask spread. This research data is obtained from the company's monthly data from 2019 to 2020. The results of the analysis show that stock prices and stock trading volume affect the bid-ask spread, while stock returns and return variances do not affect the bid-ask spread. Meanwhile, simultaneously, stock prices, stock returns, stock trading volume, and return variance affect the bid-ask spread. This research data is obtained from the company's monthly data from 2019 to 2020. The results of the analysis show that stock prices and stock trading volumes affect the bidask spread, while stock returns and return variances do not affect the bid-ask spread. Meanwhile, simultaneously, stock prices, stock returns, stock trading volume, and return variance affect the bid-ask spread.
\end{abstract}

Keywords: Stock price, stock return, stock trading volume, return variance, bid-ask spread

\section{INTRODUCTION}

A capital market is a place where various parties, especially companies, sell stocks and bonds with the aim that the proceeds from these sales will be used as additional funds to strengthen the company's capital (Fahmi, 2015: 36). The capital market has an important role in the economy. a country because the capital market performs two functions, namely first as a means for business funding or as a means for companies to obtain funds from the investor community. The two capital markets are a means for the public to invest in financial instruments such as stocks, bonds, mutual funds, and others. Thus, the community can place their funds according to the characteristics of their respective benefits and risks (Martalena, et al, 2011: 3).

PT. Sri Rejeki Isman Tbk (SRIL) in today's trading on April 3, 2020, fell sharply. This is in line with the bustling stock trading of the textile and garment issuer, which topped the list of top transaction values today. As of the close of trading today, the price of the SRIL coded stock fell 12 percent to Rp 308 from the previous close of Rp 350. In terms of transactions, SRIL shares were in the second largest volume, with 1.95 billion shares changing hands with the highest transaction value. on the Indonesia Stock Exchange, which reached $\mathrm{Rp} 638$ billion. The stock transaction of the issuer of this military uniform manufacturer reached 9 percent of transactions on the Exchange today.Interestingly, every time SRIL's stock price has gone down or up significantly in the last three trading days, this one broker is always recorded as making the biggest sales or purchases. Even the transaction is far above other brokers today, Mandiri Sekuritas (CC) is again the 
biggest seller and buyer of shares in this military uniform manufacturer. From Bareksa's observation, CC sold 7.8 million lots of shares at an average price of Rp 326.7 per share, valued at $\mathrm{Rp} 253.9$ billion.

According to (Hanousek and Podpiera, 2002) in Gusti, I. Ayu, (2015), Changes in price and trading volume due to the announcement of the company's stock split, causing shareholders to obtain capital gains must know one of the components of costs in stock trading, namely bid-ask spreads. Bid-ask spread is an important determinant of trading costs and thus has a significant impact on financial market performance, thus becoming a major focus of research.According to Sri (in Chatijah, Siti, 2010) stock players or investors need to have much information related to the dynamics of stock prices to make decisions about company shares that are worthy of being selected. Knowledge of the bid-ask spread is very necessary for investors, especially those who expect to obtain capital gains because this is seen as one of the cost components in stock trading. Several studies have been conducted, Nurul (2009) analyzed stock prices on the bid-ask spread. The study concludes that stock prices do not affect the bid-ask spread. This is different from research by Anugrah, et al (2014) which shows that stock prices have a significant influence on the bid-ask spread of Islamic stocks.

The results of research by Dwi (2009) found a significant positive effect of stock returns on the bidask spread of stocks. On the other hand, Purwani (2008) found that stock returns have no significant effect on the bid-ask spread.Made, et al (2005) found that stock trading volume has no significant effect on the bidask spread of companies in the LQ45 index on the Indonesia Stock Exchange. This means that stock trading volume has no significant effect on the bid-ask spread of companies in the LQ45 index. In other words, stock trading volume has an insignificant but not significant effect on the increase or decrease in the bid-ask spread.Anugrah, et al (2014) analyzed the return variance on the bid-ask spread. The researcher concludes that the stock return variance has a significant effect on the bid-ask spread of Islamic stocks. On the other hand, Gusti et al. (2015) found that the return variance does not affect the bid-ask spread for companies that do stock splits.In this study, the authors want to prove that the bid-ask spread can be influenced by stock prices, stock returns, stock trading volume, and stock return variances. This research was conducted on textile and garment companies because of the occurrence of soil stock transactions when they fell or rose sharply (Bareksa.com).

\section{Research purposes}

This research aims to:

1. To obtain empirical evidence that stock prices affect the bid-ask spread of stocks.

2. To obtain empirical evidence that stock returns affect the bid-ask spread of stocks.

3. To obtain empirical evidence, the volume of stock trading affects the bid-ask spread of the stock.

4. To obtain empirical evidence that the variance of return affects the bid-ask spread of stocks.

5. To obtain empirical evidence of stock prices, stock returns, stock trading volume, and variance of returns affect the bid-ask spread of stocks.

\section{LITERATURE REVIEW}

Signaling Theory

Signaling theory is a theory that looks at signs about conditions that describe a company (Fahmi, 2015: 106). Whatever information occurs from the condition of a company's shares, it always affects investment decisions as to the party that catches the signal. The concept of signaling theory is a theory that discusses the rise and fall of prices in the market so that it will influence investor decisions (Fahmi, 2015: 86).

\section{Investation}

According to Abdul Halim, investment is essentially the placement of some funds at this time in the hope of obtaining profits in the future (Fahmi, 2015: 4).According to PSAK No. 13 in Financial Accounting Standards as of October 1, 2004, investment is an asset used by the company for wealth growth (accretion of wealth) through the distribution of investment returns (such as interest, royalties, dividends, and rent), for the 
appreciation of the value of the investment, or other benefits to the investing company such as benefits obtained through trading relationships. Inventories and open fixed assets are investments (Fahmi, 2015: 5).

\section{Efficient Capital Market}

efficient market (market efficient) is a condition where information about all prices can be obtained openly and quickly without any special obstacles (Fahmi, 2015: 213).Formally, an efficient capital market is defined as a capital market with security prices reflecting all relevant information. The faster new information is reflected in the price of a security, the more efficient is the capital market. (Martalena, et al, 2011: 41).The basic concept of an efficient capital market is a by-product of research by Maurice Kendall with the subject of research on commodity and stock price behavior. The goal is to separate the regular price cycles, but they couldn't find the cycle. Prices seem to follow a random walk which means that prices will change in the future. The increase and decrease in stock prices are following the information received in the capital market (Martalena, et al, 2011: 41).

\section{Bid-Ask Spread}

In general, the purchase price (bid price) is lower than the actual price and the selling price (ask price) is usually higher than the actual price. The cost of ownership represents the trade-off between owning too much stock and owning too little stock. The number of shares held at least can also be shown by how long the trader has held these shares. Opportunity costs are the largest part of the cost of owning shares. Order processing costs include, among others, administration, reporting of computer processes, telephone, and others. Meanwhile, the cost of information asymmetry was born due to the existence of two traders who are not the same in owning and accessing information. The first part is an informed trader who has superior information, and the other party is a uniformed trader who is inferior in information (Supardi, 2010).

\section{Stock price}

The share price is the present value of the cash flows that will be received by shareholders in the future. The stock market price is formed through the mechanism of supply and demand in the capital market. Hartono (2013: 152) states that the share price consists of the nominal value of a share which is determined for each share. From some of the definitions above, it can be concluded that stock prices usually occur in demand and supply of capital market participants which are related to the value of a stock in the eyes of investors which always increases or decreases.

\section{Return Stock}

Return is the return on investment. Returns can be in the form of realized returns that have occurred or expected returns that have not yet occurred but are expected to occur in the future (Hartono, 2013: 235). Returnrealization (realized return) is the return that has occurred. Realized return is calculated using historical data. Realized return is important because it is used as a measure of the company's performance. Realized returns or historical returns are also useful as a basis for determining expected returns and future risks (Hartono, 2013: 235).

\section{Volume Stock trades}

According to Jones (2010) in Veronica (2013), volume Trading is a part of technical analysis. High trading volume is considered to be in line with rising prices. Stock trading volume is the ratio between the number of shares traded to the number of shares outstanding at a certain time. To make investment decisions, a rational investor will consider the risks and expected returns.For this reason, investors should analyze before determining the shares they will buy. To perform analysis investors need information. The existence of published information will change the confidence of investors which can be seen from the market reaction. One of the market reactions is the trading volume reaction.

\section{Return Variant}

According to Fitriyah (2012) in Muhammad, et al (2014) states that the return variance shows return variability around normal returns due to stock volatility (price fluctuations). The higher the return variance, the more varied the daily returns obtained by investors. this reflects high market uncertainty (risk) causing dealers to try to cover it with larger spreads. 


\section{Conceptual Framework}

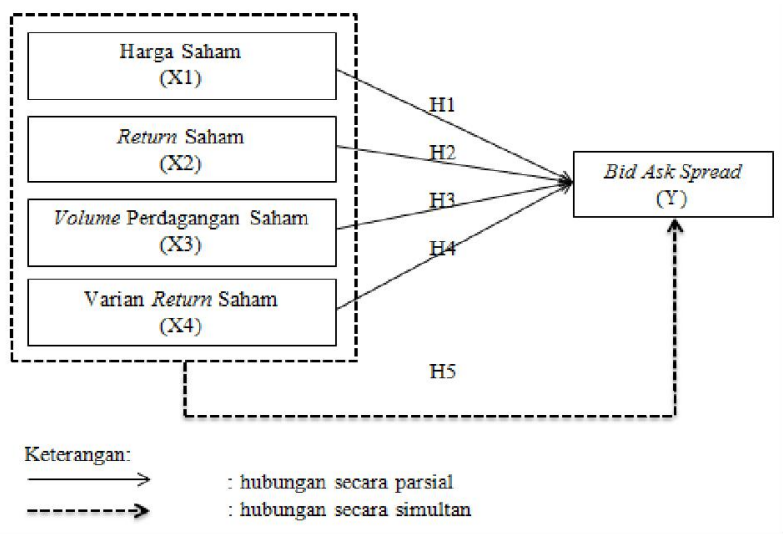

\section{Hypothesis}

H1: The stock price affects Bid-Ask Spread Stock

H2: Return Stocks affect the Bid-Ask Spread of Stocks

H3:The volume of stock trading affects the Bid-Ask Spread of the stock

H4: Variant Return affect the Bid-Ask Spread of Stocks

H5: Stock price, Return Stocks, Stock Trading Volume, and Return Variants affect the Bid-Ask Spread of the stock

\section{RESEARCH METHODS}

The data used in this study is secondary data in the form of financial data of textile and garment companies listed on the IDX for the period 2019-2020. The results of the calculation of the data were developed using multiple linear regression, but before testing with descriptive statistics, the researcher will test the classical assumptions with the help of SPSS 20.

\section{ANALYSIS AND DISCUSSION}

\section{Descriptive statistics}

Descriptive statistical analysis in this study presents data in the form of average values (mean), standard deviation, minimum, maximum. The data is presented in the following table:

Table 1. Descriptive Statistics

\section{Descriptive Statistics}

\begin{tabular}{|c|c|c|c|c|c|}
\hline & $\mathrm{N}$ & $\begin{array}{l}\text { Mini } \\
\text { mum }\end{array}$ & $\begin{array}{l}\text { Maxi } \\
\text { mum }\end{array}$ & $\begin{array}{c}\text { mea } \\
n\end{array}$ & \begin{tabular}{|c} 
Std. \\
Deviatio \\
$\mathrm{n}$
\end{tabular} \\
\hline stock price & 309 & 50 & $\begin{array}{r}1747 \\
5\end{array}$ & $\begin{array}{r}856 . \\
13\end{array}$ & $\begin{array}{r}2826,08 \\
8\end{array}$ \\
\hline stock returns & 309 & -.92 & .60 & .001 & .15792 \\
\hline $\begin{array}{l}\text { volume_tradin } \\
\text { g_stock }\end{array}$ & 309 & .00 & .48 & $\begin{array}{r}.035 \\
1\end{array}$ & .07027 \\
\hline variant_return & 309 & .00 & .03 & $\begin{array}{r}.001 \\
0\end{array}$ & .00305 \\
\hline $\begin{array}{l}\text { bid_ask_aprea } \\
\text { d } \\
\text { Valid N } \\
\text { (listwise) }\end{array}$ & $\begin{array}{l}309 \\
309\end{array}$ & -2.00 & 2.00 & $\begin{array}{r}298 \\
1\end{array}$ & .65466 \\
\hline
\end{tabular}

From the table the results of the descriptive statistical test can be explained as follows:

1. The value of the stock price obtained the smallest value of 50, the largest value is 17475 , the average value is 856.13 with a standard deviation of 2826,088 .

2. The value of stock return obtained the smallest value of -0.92 , the largest value is 0.60 , the average value is 0.0016 , with a standard deviation of 0.15792 . 
3. The value of stock trading volume obtained the smallest value of 0.00 , the largest value of 0.48 , the average value of 0.0351 , with a standard deviation of 0.07027 .

4. The value of stock return variance obtained the smallest value of 0.00 , the largest value is 0.03 , the average value is 0.0010 , with a standard deviation of 0.00305 .

5. The value of the bid-ask spread for shares obtained the smallest value of -2.00 , the largest value of 2.00, the average value of 0.2981 , with a standard deviation of 0.65466 .

\section{Classic assumption test}

Table 2. Normality Test

One-Sample Kolmogorov-Smirnov Test

\begin{tabular}{|ll|r|}
\hline & & $\begin{array}{r}\text { Unstandardize } \\
\text { d Residual }\end{array}$ \\
\hline $\mathrm{N}$ & 132 \\
Normal & mean & OE-7 \\
Parameters, & Std. & .70750396 \\
$\mathrm{~b}$ & Deviation & .099 \\
Most & Absolute & .099 \\
Extreme & Positive & -.089 \\
Differences & negative & 1.133 \\
Kolmogorov-Smirnov Z & .153 \\
\hline asymp. Sig. (2-tailed)
\end{tabular}

a. Test distribution is Normal.

b. Calculated from data.

Data Source: SPSS Calculation Results

The results of the normality test using the Kolmogorov-Smirnov non-parametric statistical test showed that the Kolmogorov-Smirnov value was 1.133 with asymp. Significant (2-tailed) 0.153 . Because the significant level is greater than $0.05(\alpha>0,05)$ it can be concluded that the residual data are normally distributed and the regression model is feasible to be used in this study. The results of the normality test using the Kolmogorov-Smirnov non-parametric statistical test showed that the Kolmogorov-Smirnov value was 1.133 with asymp. Significant (2-tailed) 0.153 . Because the significant level is greater than $0.05(\alpha>0,05)$ it can be concluded that the residual data are normally distributed and the regression model is feasible to be used in this study.

Multicollinearity Test

Table 3. Multicollinearity Test

\begin{tabular}{|c|c|c|}
\hline \multirow{2}{*}{ Model } & \multicolumn{2}{|c|}{ Collinearity Statistics } \\
\hline & Tolerance & VIEW \\
\hline (Constant) & & \\
\hline stock price & .990 & 1.010 \\
\hline volume_trading_stock & .939 & 1.065 \\
\hline variant_return & .587 & 1,704 \\
\hline stock returns & .612 & 1,635 \\
\hline
\end{tabular}

Dependent Variable: bid_ask_spread

Data Source: SPSS Data Calculation Results 
From the output above, it can be seen that the value of tolerance of each independent variable is more than 0.10 and the VIF value of each independent variable is not more than 10 . Therefore, it can be concluded that there is no multicollinearity between independent variables in the regression model.

\section{Heteroscedasticity Test}

Table 4. Heteroscedasticity Test

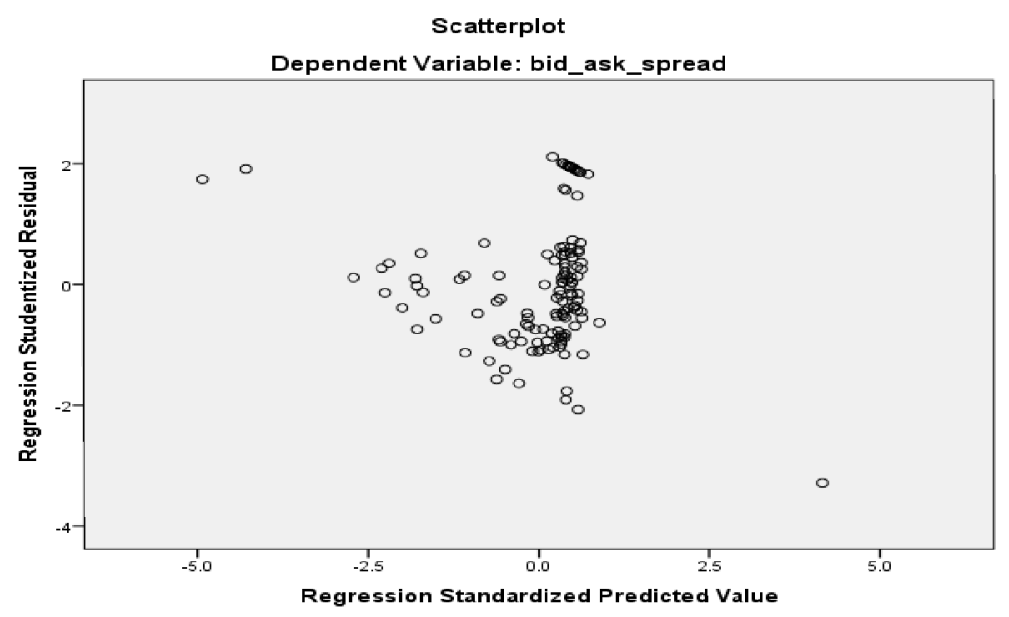

Based on the picture above, it can be seen that the data does not form a certain pattern and the points spread above and below zero on the $\mathrm{Y}$ axis, so there is no heteroscedasticity. Analysis with graph plots has a significant weakness because the number of observations affects the results so that statistical tests are needed that can guarantee the accuracy of the results (Ghozali, 2016: 136). The statistical test used to detect the presence or absence of heteroscedasticity is the lesser test. The heteroscedasticity test can be determined by looking at the probability value $>0.05$ then there is no heteroscedasticity.

\section{Autocorrelation Test}

Table 5. Autocorrelation Test

\section{Model Summary}

\begin{tabular}{|l|l|r|r|r|l|}
\hline Model & $\mathrm{R}$ & $\begin{array}{c}\mathrm{R} \\
\text { Square }\end{array}$ & $\begin{array}{c}\text { Adjusted } \\
\text { R Square }\end{array}$ & $\begin{array}{c}\text { Std. The } \\
\text { error of the } \\
\text { Estimate }\end{array}$ & $\begin{array}{l}\text { Durbin } \\
\text { Watson }\end{array}$ \\
\hline 1 & $.432 \mathrm{a}$ & .187 & .173 & .60548001 & 1,885 \\
\hline
\end{tabular}

a.Predictors: (Constant), res2

\section{b. Dependent Variable: Unstandardized Residual}

Data Source: SPSS Calculation Results

The results of the autocorrelation test which can be seen in the table above show that the value of DurbinWaston (DW) obtained is 1.885 . This value will be compared with the table value using a significance value of 5 percent. The number of samples is $309(\mathrm{n}=309)$ and the number of independent variables is $4(\mathrm{k}=4)$. From the comparison results with the Durbin-Waston (DW) table, the values of $\mathrm{dl}=1.79422$ and $\mathrm{du}=$ 1.83329 are obtained. Therefore, the Durbin Waston (DW) value of 1.885 is greater than the upper limit (du) and less than $4-1.83329(4-\mathrm{du}=4-1)$. 
Table 6. Regression Analysis

\section{Coefficients}

\begin{tabular}{|c|c|c|c|}
\hline \multirow{2}{*}{ Model } & \multicolumn{2}{|c|}{$\begin{array}{c}\text { Unstandardized } \\
\text { Coefficients }\end{array}$} & \multirow{2}{*}{\begin{tabular}{|c}
$\begin{array}{c}\text { Standardiz } \\
\text { ed } \\
\text { Coefficient } \\
\text { s }\end{array}$ \\
Beta
\end{tabular}} \\
\hline & $B$ & $\begin{array}{l}\text { Std. } \\
\text { Error }\end{array}$ & \\
\hline (Constant) & $-1,245$ & .225 & \\
\hline stock price & $\begin{array}{r}9.884 \mathrm{E}- \\
005\end{array}$ & .000 & .175 \\
\hline $\begin{array}{l}\text { volume_tr } \\
\text { ading sto }\end{array}$ & -5.823 & .925 & -.490 \\
\hline & & & \\
\hline $\begin{array}{l}\text { variant_ret } \\
\text { urn }\end{array}$ & 16,424 & 31,746 & .051 \\
\hline $\begin{array}{l}\text { stock } \\
\text { returns }\end{array}$ & -.082 & .163 & -.049 \\
\hline
\end{tabular}

a. Dependent Variable: bid_ask_spread

Data Source: SPSS Calculation Results

Ask Spread $=-1.245+9.884 \mathrm{E}-005 \mathrm{X} 1-5.823 \mathrm{X} 3+16,424 \mathrm{X} 4-0.082 \mathrm{X} 2$

From the above equation it can be explained as follows:

The results of the regression coefficients show that the constant of -1.246 states that if the stock price variable, return stocks, stock trading volume, and return variance is 0 , then the bid-ask spread is -1.246 .

The regression coefficient on the stock price variable is $9.884 \mathrm{E}-005$, this indicates that if the stock price variable increases by percent, and considers other variables, namely return stock, stock trading volume, and return variance are constant, it will cause the bid-ask spread to increase by $9.884 \mathrm{E}-005$.

The regression coefficient on variable return stock is -0.082 , this indicates that if the stock return variable increases by percent, and considers other variables namely stock price, stock trading volume, and return variance to be constant, it will cause the bid to ask spread to decrease by 0.082 .

The regression coefficient on variable volume stock trading is -5.823 , this indicates that if the stock trading volume variable increases by a percentage, and considers other variables namely stock prices, stock returns, and return variances to be constant, it will cause the bid-ask spread to decrease by 5.823.The regression coefficient on the return variance variable is 16,424 , this indicates that if the return variance variable increases by how much percent, and considers other variables, namely stock prices, stock returns, and stock trading volume, to be constant, it will cause the bid-ask spread to increase by 16,424 .

\section{Hypothesis test}

\section{Coefficient of Determination}

Table 7.Coefficient of Determination

Model Summary

\begin{tabular}{|c|c|c|c|c|}
\hline Model & $\mathrm{R}$ & $\mathrm{R}$ & Adjusted & Std. \\
& & Square & $\mathrm{R}$ & The \\
& & & Square & $\begin{array}{c}\text { error } \\
\text { of the } \\
\end{array}$ \\
& & & & $\begin{array}{c}\text { Estim } \\
\text { ate }\end{array}$ \\
\hline
\end{tabular}




\begin{tabular}{|r|r|r|r|r|}
\hline 1 & $.525 a$ & .275 & .253 & .7185 \\
6
\end{tabular}

Predictors: (Constant), return_stock, price_share,

volume_trading_stock, varian_return

Dependent Variable: bid_ask_spread

Data Source: SPSS Calculation Results

From the table above, it can be seen that the Adjusted R Square value is 0.253 , this means that $25.3 \%$ of the stock bid-ask spread variable can be explained by the independent variables of stock prices, stock returns, stock trading volume, and stock return variances, while the remaining $74.7 \%$ explained by other variables outside this research model.

\section{Individual Parameter Significant Test (Test Statistical t)}

Table 8.Test $t$

\section{Coefficients}

\begin{tabular}{|l|r|r|c|l|}
\hline \multirow{2}{*}{ Model } & \multicolumn{2}{|c|}{$\begin{array}{l}\text { Unstandardized } \\
\text { Coefficients }\end{array}$} & \multirow{2}{*}{ Sig. } \\
\cline { 2 - 4 } & \multicolumn{1}{|c|}{$\mathrm{B}$} & \multicolumn{1}{c|}{$\begin{array}{c}\text { Std. } \\
\text { Error }\end{array}$} & & \\
\hline (Constant) & $-1,245$ & .225 & -5.535 & .000 \\
stock price & $\begin{array}{r}9.884 \mathrm{E}- \\
005\end{array}$ & .000 & 2,309 & .023 \\
1 volume_tradin & -5.823 & .925 & -6.292 & .000 \\
g_stock & 16,424 & 31,746 & .517 & .606 \\
variant_return & -.082 & .163 & -.503 & .616 \\
stock returns & &
\end{tabular}

a. Dependent Variable: bid_ask_spread

Data Source: SPSS Calculation Results

Based on the table above, it shows that the t-count of the stock price variable (X1) is 2.309 with a significance of $0.023(\alpha<0.05)$, it can be concluded that $=2.309>=1.64986$. So, it can be concluded that the stock price variable affects the bid-ask spread. The stock return variable (X2) is -0.503 with a significance of $0.616(\alpha>0.05)$, it can be concluded that $=-0.503<=1.64986$ so it can be concluded that the stock return variable does not affect the stock bid-ask spread. The stock trading volume variable (X3) is 6.292 with a significant level of $0.000(\alpha<0.05)$, it can be concluded that $=6.292>=1.64986$ so it can be concluded that the stock trading volume variable affects the stock bid-ask spread. A negative $t$ value indicates that the stock trading volume (X3) has an opposite relationship with the bid-ask spread. So it can be concluded that the volume of stock trading influences the bid-ask spread of the stock. The return variance variable (X4) is 0.517 with a significant $0.606(\alpha>0.05)$, it can be concluded that $=0.517<=1.64986$ so it can be concluded that the stock return variance variable has no effect on the stock bid-ask spread.t $t_{\text {hitung }} t_{\text {tabel }} t_{\text {hitung }}>t_{\text {tabel }} \mathrm{t}_{\text {hitung }} t_{\text {tabel }} \mathrm{t}_{\text {hitung }} t_{\text {tabel }} \mathrm{t}_{\text {hitung }} t_{\text {tabel }}$

The first hypothesis (H1) is that the stock price affects the bid-ask spread of the stock. From the regression analysis test (table 4.8), the t-count value is 2.309 with a significant value of $0.023(\alpha<0.05)$, then the stock price variable affects the stock bid-ask spread, which means H1 is accepted.The second hypothesis (H2) is that stock returns affect the stock bid-ask spread. From the regression analysis test (table $4.8)$, the t-count value is -0.503 with a significance of $0.616(\alpha>0.05)$, then the stock return variable does not affect the stock bid-ask spread, which means $\mathrm{H} 2$ is rejected.The third hypothesis (H3) is that the volume of stock trading affects the bid-ask spread of the stock. From the regression analysis test (table 4.8), the tcount value is 6.292 with a significant value of $0.000(\alpha<0.05)$, then the stock trading volume variable hurts the stock bid-ask spread, which means H3 is accepted.The fourth hypothesis (H4) is that the stock return variance affects the stock's bid-ask spread. From the regression analysis test (table 4.8), the t-count value is 
0.517 with a significant value of $0.606(\alpha>0.05)$, then the stock return variance variable does not affect the stock bid-ask spread, which means $\mathrm{H} 4$ is rejected.

Overall Significance Test of Sample Regression (F Statistical Test)

Table 9. F . test

\section{ANOVA}

\begin{tabular}{|l|c|r|c|c|r|}
\hline Model & $\begin{array}{c}\text { Sum of } \\
\text { Square } \\
\text { s }\end{array}$ & $\begin{array}{c}\text { df } \\
\text { Mean } \\
\text { Squar } \\
\mathrm{e}\end{array}$ & $\mathrm{F}$ & Sig. \\
\hline $\begin{array}{l}\text { Regressi } \\
\text { on }\end{array}$ & 24,915 & 4 & 6.229 & $\begin{array}{r}12.06 \\
4\end{array}$ & $\begin{array}{r}.000 \\
\mathrm{~b}\end{array}$ \\
1 Residual & 65.574 & $\begin{array}{r}12 \\
7\end{array}$ & .516 & & \\
13 & & & \\
Total & 90,489 & & & \\
\hline
\end{tabular}

a. Dependent Variable: bid_ask_spread

b. Predictors: (Constant), return_stock, price_share, volume_trading_stock, varian return

Data Source: SPSS Calculation Results

From the $\mathrm{F}$ test analysis table above, it can be seen that the calculated $\mathrm{F}$ is 12.064 with a significance of $0.000(\alpha<0.05)$. Then the magnitude of the $\mathrm{F}$ table is $2.63 \mathrm{soF}_{\text {hitung }}>$ namely $12.064>2.63$, it can be concluded that the independent variable in this research model affects the dependent variable, namely, the stock bid asks spread. Based on the results of the F test analysis, it can be seen from the hypotheses as follows: $F_{\text {abel }}$

The fifth hypothesis (H5) is that the stock price, stock return, stock trading volume, and stock return variance affect the stock bid-ask spread. From the results of the regression analysis test (table 4.9) obtained F count of 12.064 with a significance level of $0.000(\alpha>0.05)$, then the stock price variables, stock returns, stock trading volume, and return variance affects the stock bid-ask spread, which means H5 is accepted.

\section{CONCLUSIONS}

Based on the results of the study, the following conclusions can be drawn:

1. The test results show that stock prices affect the bid-ask spread of stocks in textile and garment companies in 2019-2020.

2. The test results show that stock returns do not affect the bid-ask spread of stocks in textile and garment companies in 2019-2020.

3. The test results show that the volume of stock trading affects the bid-ask spread of shares in textile and garment companies in 2019-2020

4. The test results show that the stock return variance does not affect the bid-ask spread of stocks in textile and garment companies in 2019-2020

5. The test results show that there is an influence between stock prices, stock returns, stock trading volume, and stock return variants on the bid-ask spread of stocks in textile and garment companies in 2019-2020.

\section{REFERENCE}

[1] Anggraini, Viri., Hartini, Titin., \& Wijaya, Trisnadi. (2013). Effect of Stock Price, Trading Volume, and Company Size on Bid-Ask Spread on Food and Beverage Companies Listed on the Indonesia Stock Exchange.

[2] Anugrah, Muhammad, Perdana., \& Titik, Farida, Kristanti. (2014). The Effect of Variant Return, Stock Price, Trading Volume, Earning Per Share on the Bid-Ask Spread of Sharia Stocks (Empirical Study on Companies Listed on the Jakarta Islamic Index 2010-2012). 
[3] Aprilia, Zelda. (2015). Factors Affecting the Bid-Ask Spread of LQ-45 Stocks on the Indonesia Stock Exchange.

[4] Bidara, Leoni, Rasyidi., \& Murdayanti, Yunika., (2013). The Effect of Asset Size, Closing Price, Liquidity, Return Variant, and Stock Trading Volume on Bid-Ask Spread on Real Estate and Property Companies Listed on the IDX.

[5] Chatijah, Siti. (2010). Analysis of the Effect of Price, Trading Volume, Return, Trading Frequency, and Stock Price Volatility, on the Bid-Ask Spread of Companies Conducting Stock, Splits for the 2004-2008 Period.

[6] Bi, Sri, Ari, Ambarwati. (2009). The Effect of Stock Returns, Stock Trading Volumes, and Stock Return Variants on the Bid-Ask Spread of Stocks in Manufacturing Companies Included in the Lq 45 Index for the Period 2003-2005.

[7] Fahmi, Irham. (2015). Introduction to Portfolio Theory and Investment Analysis. Bandung; Alphabet.

[8] Ghozali, priest. (2016). Application of Multivariate Analysis (8th ed). Semarang ; Diponegoro University publishing body.

[9] Gusti, I. Ayu, Mas, Widhyawati., \& Eka, IGA Damayanthi. (2015). Effect of Trading Volume, Market Value, and Return Variance on Bid-Ask Spread.

[10] Halim, Abdul. (2015). Investment Analysis And Its Application. Jakarta; Salemba Four.

[11] Hartono, Jogiyanto. (2013). Portfolio Theory and Investment Analysis. Yogyakarta ; BPFE.

[12] http://www.bareksa.com/id/text/2017/04/03/broker-ini-always-dibalik-transaksi-saham-sril-saat-turun-ataunaik-tajam/15239/news.

[13] Made, Ni, Wahyuliantini., \& Agung, Anak, Gede, Suarjaya. (2015). The Effect of Stock Price, Stock Trading Volume, And Stock Return Volatility on Bid-Ask Spread.

[14] Marlena, SE., MM. \& Maya, Malinda (2011). Introduction to Capital Markets. Bandung: Andi.

[15] Napitupulu, Veronica. \& Syahyunan. (2013). The Effect of Stock Return, Trading Volume, and Stock Price Volatility on the Bid Asks Spread in Companies Conducting Stock Splits on the Indonesia Stock Exchange.

[16] Nurul, Lulu, Istanti. (2009). Effect of Stock Price, Trading Volume Activity and Stock Risk on Bid-Ask Spread (Study on LQ-45 Company in Jakarta Stock Exchange).

[17] Purwani, Ratih. (2008). The Effect of Stock Return, Stock Trading Volume, and Stock Trading Frequency on the Bid-Ask Spread in Companies Conducting Stock Splits on the Indonesia Stock Exchange.

[18] Rusdin. (2008). Capital market. Bandung; Alphabet.

[19] Shobriati, Ikrima., Darminto. \& Wi, MG, Endang. (2013). The Effect of Stock Prices, Stock Trading Volumes and Return Variants on Bid-Ask Spreads Around the Announcement Stock Split (Study on Companies Listed on the Indonesia Stock Exchange from 2005 to 2011).

[20] Sugiyono. (2015). Quantitative research methods and R \& D. Bandung; Alphabet.

[21] Supardi. (2010). Analysis of the Effect of Stock Return and Stock Trading Volume on Bid-Ask Spread Pre and Post Announcement of Financial Statements at LQ 45.

[22] www.idx.com

[23] www. yahoo.finance 